\title{
Pengaruh Etos Kerja Islami Dan Komitmen Organisasi Terhadap Kinerja Karyawan Bank Tabungan Negara Syariah (BTN) KC Malang
}

\author{
Derry Pratama Citra, Agus Purwadi, Imamul Hakim \\ Program Studi Ekonomi Syariah, \\ Fakultas Agama Islam, Universitas Muhammdiyah Malang \\ Email: derrypratamac@gmail.com
}

\begin{abstract}
This study aims to determine the influence of Islamic work ethic and organizational commitment to the performance of employees of the BTN Syariah Malang Branch in 2018. This study uses a quantitative approach with multiple linear regression analysis method. The results of this study indicate that based on multiple linear regression analysis test results ( $t$ test) note that Islamic work ethic has a significant effect on employee performance. Likewise with organizational commitment that gives a significant effect on employee performance. Multiple linear regression analysis simultaneously (f test) known that the two independent variables of Islamic work ethic and organizational commitment have a significant effect on employee performance. The results of this study concluded that Islamic work ethic and organizational commitment has a significant effect on employee performance.
\end{abstract}

Keywords: Ethos of Islamic Work, Organizational Commitment, Employee Performance. 


\begin{abstract}
ABSTRAK
Penelitian ini bertujuan untuk mengetahui pengaruh etos kerja Islami dan komitmen organisasi terhadap kinerja karyawan Bank Tabungan Negara Syariah KC Malang tahun 2018. Penelitian ini menggunakan pendekatan kuantitatif dengan metode analisis data regresi linier berganda. Hasil penelitian ini menunjukkan bahwa berdasarkan hasil uji analisis regresi linier berganda secara parsial (uji t) diketahui bahwa etos kerja Islami berpengaruh signifikan terhadap kinerja karyawan. Begitu juga dengan komitmen organisasi yang memberikan pengaruh yang signifikan terhadap kinerja karyawan. Uji analisis regresi linier berganda secara simultan (uji f) diketahui bahwa kedua variabel independen yaitu etos kerja Islami dan komitmen organisasi berpengaruh signifikan terhadap kinerja karyawan. Kemudian nilai koefisien determinasi ( $R$ square) diketahui bahwa 28,2\% kinerja karyawan dapat dijelaskan oleh variabel etos kerja Islami dan komitmen organisasi. Sedangkan $71,8 \%$ sisanya dipengaruhi variabel lain yang tidak masuk dalam penelitian ini. Hasil penelitian ini sekaligus menjawab hipotesis peneliti yaitu: $\mathrm{H}_{1}$ : etos kerja Islami berpengaruh signifikan terhadap kinerja karyawan. $\mathrm{H}_{2}$ : komitmen organisasi berpengaruh signifikan terhadap kinerja karyawan. $\mathrm{H}_{3}$ : etos kerja Islami dan komitmen organisasi secara simultan berpengaruh signifikan terhadap kinerja karyawan.
\end{abstract}

Kata Kunci: Etos Kerja Islami, Komitmen Organisasi, Kinerja Karyawan.

\title{
1. Pendahuluan
}

Pada era modern seperti sekarang ini persaingan pada dunia perbankan mengalami peningkatan yang sangat besar, baik pada perbankan Syariah maupun perbankan konvensional. Keadaan perekonomian di era ini pun semakin terbuka, sehingga membuat persaingan dalam dunia perbankan semakin ketat. Semakin ketatnya persaingan perbankan di Indonesia, menuntut sumber daya manusia untuk bekerja secara optimal dan terus meningkatkan kualitasnya. Hal ini dikarenakan sumber daya manusia memegang peran penting guna menunjang keberhasilan suatu perusahaan atau organisasi.

Perkembangan perbankan syariah di Indonesia terus mengalami kenaikan dari waktu-kewaktu. Jumlah karyawan bank umum syariah dan unit usaha syariah pada akhir tahun 2016 tercatat sebanyak 55.597 karyawan, terus mengalami peningkatan menjadi 56.476 pada pertengahan tahun 2017 (OJK, 2017: 4). Hal ini membuat kebutuhan sumber daya manusia yang kompeten serta memiliki komitmen pada perbankan syariah akan terus meningkat. Perkembangan bank syariah sendiri tidak hanya ditentukan oleh pembukaan jaringan informasi dan 
perluasan kantor cabang saja, akan tetapi sangat ditentukan oleh sumber daya manusia yang berkualitas. Sehingga perbankan syariah dapat menjalankan fungsinya sebagai lembaga keuangan yang berlandaskan prinsip-prinsip syariah dengan baik.

Dalam meningkatkan kualitas sumber daya manusia, manajemen perusahaan perlu melakukan pendekatan baik dari segi agama, psikologi, budaya, dan organisasi. Mangkunegara berpendapat bahwasannya prestasi kerja yang baik dari individu maupun organisasi di era modern ini perlu dilandasi dengan pendekatan agama, psikologi, dan budaya (Mangkunegara, 2005: 5). Adanya pendekatan tersebut akan menjadikan norma atau karakteristik yang baik dalam bekerja sehingga karyawan diharapkan mampu memberikan kinerja yang memuaskan. Adanya pengelolaan SDM yang baik akan mempengaruhi kinerja perusahaan yang baik. Kinerja yang baik dapat tercermin dari perilaku setiap individu karyawan. Apabila bekerja dengan semangat dan memiliki komitmen bekerja yang tinggi maka akan memberikan hasil yang memuaskan pada perusahaan. Hal yang dapat dilakukan perbankan syariah dalam meningkatkan kinerja perusahaannya salah satunya dengan cara menerapkan etos kerja yang baik.

Etos kerja adalah pedoman manusia dalam bekerja berdasarkan norma atau aturan yang ada baik dari segi agama, budaya, ataupun kebiasaan. Etos kerja mendorong manusia untuk melakukan segala sesuatu dengan baik guna menghasilkan sebuah karya atau produk yang maksimal. Buchori (1994: 6) berpendapat bahwa etos kerja merupakan sikap maupun sifat mengenai cara bekerja yang dimiliki oleh seseorang, kelompok manusia, atau suatu bangsa. Etos kerja seseorang merupakan bagian dari tata nilai individual, begitu juga etos kerja kelompok masyarakat menjadi tata nilai pada masyarakat. Pada setiap organisasi, etos kerja yang diterapkan memiliki perbedaan. Hal ini dipengaruhi pada norma budaya, agama, maupun kebiasaan yang dianut. Begitu juga dengan penerapan etos kerja pada perbankan syariah, yang tentunya memiliki perbedaan dengan perbankan konvensional maupun dengan lembaga keuangan lainnya. Menurut UU 10 tahun 1998, dan UU No.21 tahun 2008 tentang perbankan menyebutkan terdapat dua hal penting yakni: prinsip yang dipakai oleh perbankan syariah adalah prinsip hukum Islam, serta adanya pihak yang berwenang dalam mengeluarkan fatwa yang menjadi landasan bank syariah menjalankan operasionalnya (OJK, 8/3/2018). Hal ini yang kemudian membuat perbankan syariah memiliki ciri khas dalam menjalankan aktifitas serta pengelolaan sumber daya manusianya. Salah satunya dapat terlihat dari etos kerja yang diterapkan yakni etos kerja Islami.

Etos kerja Islami adalah etika kepribadian yang melahirkan keyakinan mendalam bahwasannya bekerja bukan hanya untuk mencapai tujuan duniawi saja, melainkan juga sebagai suatu sarana memfasilitasi dirinya untuk beramal shaleh karena memiliki nilai ibadah yang tinggi (Tasmara, 2002: 27). Etos kerja Islam tercermin dari sikap individu yang melakukan pekerjaan dengan semangat 
ibadah serta dilandasi dengan ilmu pengetahuan. Individu yang memiliki etos kerja Islami akan memberikan keuntungan kepada perusahaan, yakni dapat menghasilkan kinerja yang memuaskan. Selain etos kerja Islami ada variabel lain yang dapat mempengaruhi kinerja individu karyawan, yakni komitmen dalam berorganisasi.

Menurut Robbins (2001: 123), komitmen organisasi adalah keadaan seseorang memiliki ikatan yang kuat terhadap organisasinya dan memiliki tekat untuk meraih kesuksesan, sehingga berkomitmen untuk bertahan dengan organisasi tersebut. Selanjutnya, Luthans (2006) menyatakan bahwa komitmen organisasi adalah berusaha menempatkan dirinya dengan baik dan bekerja keras serta berkomitmen setia pada organisasi demi tercapainya tujuan organisasi. Adanya komitmen yang kuat pada setiap karyawan maka akan menumbuhkan semangat dalam bekerja serta memberikan totalitas atas kemampuannya untuk perusahaan. Hal inilah yang kemudian akan membentuk iklim kerja yang kondusif pada suatu organisasi perusahaan, sehingga tujuan atau visi dan misi perusahaan dapat segera tercapai.

Bank Tabungan Negara Syariah KC Malang merupakan bank yang menjalankan kegiatan bisnis berdasarkan prinsip-prinsip syariah. Berdirinya Bank Tabungan Negara Syariah KC Malang guna melayani tingginya keinginan masyarakat dalam memanfaatkan jasa keuangan yang berlandaskan prinsip syariah. Bank Tabungan Negara Syariah memiliki visi dan misi untuk menjadi unit bisnis yang sehat dan terkemuka dalam memberikan pelayanan jasa keuangan serta mengutamakan kemaslahatan bersama (BTN, 8/3/2018). Hingga saat ini Bank Tabungan Negara Syariah KC Malang terus eksis dan bersaing dalam memberikan serta meningkatkan kualitas pelayanan kepada nasabahnya.

\section{Kajian Pustaka}

\subsection{Etos Keja Islami}

Etos kerja Islami adalah etika kepribadian yang melahirkan keyakinan mendalam bahwasannya bekerja bukan sekedar mencapai tujuan duniawi saja, melainkan juga sebagai suatu sarana guna menfasilitasi diri beramal shaleh karena didalamnya memiliki nilai ibadah yang tinggi (Tasmara, 2002: 25). Bagi seorang muslim bekerja merupakan pengabdian dan rasa syukur kepada Allah S.W.T untuk mengelola sumber daya yang telah diberikan, karena bumi diciptakan sebagai ujian bagi mereka yang memiliki etos kerja yang terbaik (QS. AlKahfi:7). Asifudin (2004) menyatakan bahwa karakteristik etos kerja Islam adalah tentang konsep iman, ilmu, dan amal shaleh yang dapat diketahui sebagai beikut:

1) Kerja Merupakan Penjabaran Aqidah

Etos kerja dalam Islam mengajarkan untuk senantiasa melakukan pekerjaan dengan sebaik-baiknya guna menunjang kehidupan pibadi dan keluarga untuk mencapai kesuksesan di dunia maupun akhirat. Allah telah menjamin semua rezeki makhluk-makhluknya yang telah Ia ciptakan di dunia. Oleh karena itu bekerja merupakan bentuk rasa syukur atas sumber daya yang telah Allah 
berikan dan memacu setiap muslim agar mampu mengelola sumber daya yang ada dengan sebaik-baiknya. Adapun aqidah yang dapat diterapkan dalam melaksanakan pekerja diantaranya adalah: bekerja sebagai sarana ibadah kepada Allah, bekerja dilandasi keikhlasan dan mengharap ridlo Allah, dan percaya atas rizki yang Allah berikan.

2) Kerja Dilandasi Ilmu

Menuntut Ilmu meurupakan hal penting karena merupakan kewajiban atas keagamaan setiap umat muslim. Setiap muslim wajib menuntut ilmu sebagai landasan untuk beriman dan beramal shaleh. Adapun dalam bekerja ilmu digunakan sebagai penunjang guna menyelesaikan pekerjaan dengan baik sesuai dengan bidangnya. Kerja dilandasi ilmu dan iman sangatlah penting, agar kerja dapat terkendali sesuai dengan tujuan luhur. Tanpa adanya ilmu dan iman maka akan menimbulkan penyimpangan-penyimpangan dalam dunia kerja yang kemudian dapat menimbulkan dampak buruk terhadap perusahaan maupun diri sendiri. Adapun sikap kerja dilandasi ilmu adalah sebagai berikut: kreatif, aktif, memiliki perencanaan yang baik dalam bekerja, dan visioner.

3) Meneladani Sifat-Sifat Ilahiyyah Serta Mengikuti Petunjuk-Petunjuk Nya

Allah S.W.T telah memberikan potensi-potensi pada diri manusia dan dapat dihubungkan kepada sifat-sifat Ilahiyyah. Banyak sifat-sifat manusia yang mempunyai nama atau indikasi serupa dengan Asmaul Husna, namun sifat-sifat ini dalam bentuk kualitas yang jauh berbeda. Seperti contoh Allah mampu menciptakan sesuatu dari tiada menjadi ada, sedangkan manusia mampu menciptakan sesuatu yang baru dengan memanfaatkan atau mengembangkan sesuatu yang telah ada sebelumnya (Asifudin, 2004). Oleh karena itu setiap manusia memiliki potensi untuk mengembangkan sifat-sifat ilahiyyah guna mencapai etos kerja yang tinggi. Adapun kerja dengan mengikuti petunjukpetunjuk Nya dapat digali sikap hidup aktif, kreatif, percaya diri, mandiri, optimis, jujur, menghargai waktu, efektif dan efisien.

\subsection{Kineja}

Istilah kinerja berasal dari kata Job Performance atau Actual Performance yakni prestasi kerja atau prestasi sesungguhnya yang dicapai oleh seseorang. Kinerja merupakan hasil kerja yang dapat dilihat maupun diukur secara kuantitas dan kualitas yang dicapai oleh seorang pegawai dalam melakukan pekerjaannya sesuai dengan tanggung jawab yang diberikan kepadanya (Mangkunegara, 2007: 67). Henderson dalam Mangkunegara (2007: 67), menjelaskan bahwa dimensi kinerja adalah wajah suatu pekerjaan atau aktivitas yang terjadi di tempat kerja yang berhubungan terhadap pengukuran. Untuk mengukur kinerja pegawai suatu perusahaan, dimensi-dimensi kinerja dikembangkan menjadi indikator kinerja. Adapun dimensi kinerja tersebut yaitu:

\section{Hasil Kerja,}


Hasil kerja adalah keluaran (output) kerja dalam bentuk barang maupun jasa yang dapat dihitung dan diukur kualitas dan kuantitasnya pada periode kerja. hasil kerja dapat diukur dengan indikator-indikator sebagai berikut:

1) Ketepatan dalam melaksanakan pekerjaan

2) Efektivitas melaksanakan tugas

3) Kecepatan dalam melaksanakan pekerjaan

\section{Perilaku Kerja}

Perilaku kerja merupakan perilaku yang dimiliki setiap individu karyawan yang berhubungan dengan pekerjaan. Perilaku kerja sangat dibutuhkan karena merupakan persyaratan agar pekerja dapat melaksanakan pekerjaannya dengan baik dan menghasilkan kinerja yang sesuai dengan harapan perusahaan. Adapun contoh-contoh dari perilaku kerja yakni:disiplin dalam bekerja, mampu bekerja sama, dan profesional. Dari uraian diatas, dapat diketahui indikator-indikator perilaku kerja adalah sebagai berikut:

1) Disiplin dalam bekerja

2) Kerjasama

3) Profesionalisme

\section{Sifat pribadi}

Sifat pribadi yang ada hubungannya dengan pekerjaan adalah sifat yang diperlukan setiap individu pegawai atau karyawan dalam melaksanakan pekerjaannya. Adapun contoh dari sifat pribadi yang ada hubungannya dengan pekerjaan antara lain: semangat dalam melakukan pekerjaan, memiliki pengetahuan yang cukup, serta memiliki kemampuan untuk beradaptasi.

Dari uraian diatas, dapat diketahui bahwa indikator-indikator sifat pribadi dalam bekerja adalah sebagai berikut:

1) Semangat kerja

2) Pengetahuan

3) Kemampuan beradaptasi

\subsection{Komitmen Organisasi}

Menurut Robbins (2001: 123), komitmen organisasi adalah keadaan seseorang memiliki ikatan yang kuat terhadap organisasinya dan memiliki tekat untuk meraih kesuksesan, sehingga berkomitmen untuk bertahan dengan organisasi tersebut. Selanjutnya, Luthas (2006) menyatakan bahwa komitmen organisasi adalah berusaha menempatkan dirinya dengan baik dan bekerja keras serta berkomitmen setia pada organisasi demi tercapainya tujuan organisasi. Adanya komitmen yang kuat pada setiap karyawan maka akan menumbuhkan semangat dalam bekerja serta memberikan totalitas atas kemampuannya untuk perusahaan. Hal inilah yang kemudian akan membentuk iklim kerja yang kondusif pada suatu organisasi perusahaan, sehingga tujuan atau visi dan misi perusahaan dapat segera tercapai. Mayer dan Alen dalam Luthas (2006: 249) menjelaskan bahwa terdapat tiga dimensi komitmen organisasi, yaitu komitmen afektif, komitmen kelanjutan, 
dan komitmen normatif. Pertama, komitmen Afektif yang merupakan keterikatan emosional karyawan serta keterlibatan karyawan pada organisasi. Keterikatan emosional disini berupa perasaan cinta pada organisasi yang kemudian akan memunculkan kemauan untuk terus berkomitmen pada organisasi, serta membangun hubungan sosial yang baik di lingkungan organisasi. Kedua, komitmen kelanjutan, yaitu komitmen yang ditinjau berdasarkan kerugian yang terjadi apabila karyawan memutuskan untuk keluar dari suatu organisasi. Hal ini bisa timbul karena hilangnya senioritas, penghargaan, maupun benefit (gaji) apabila meninggalkan organisasi. Ketiga, komitmen Normatif, yaitu komitmen berdasarkan pada perasaan wajib untuk tetap berada dalam organisasi karena adanya kewajiban serta tanggung jawab terhadap organisasi yang didasari atas nilai norma, dan keyakinan karyawan. Karyawan yang memiliki komitmen normatif yang tinggi cenderung memperhatikan apa yang dinyatakan orang lain terhadap dirinya apabila ia memutuskan untuk meninggalkan suatu organisasi.

\section{Metode Penelitian}

Jenis yang digunakan dalam penelitian ini adalah kuantitatif. Jenis kuantitatif merupakan metode penelitian yang berdasarkan filsafat positivisme, digunakan untuk meneliti pada populasi atau sampel tertentu. Pengumpulan data menggunakan instrumen penelitian, serta analisis data bersifat kuantitatif atau statistik, dengan tujuan untuk menguji hipotesis yang telah digunakan (Sugiyono, 2016: 8). Populasi yang digunakan pada penelitian ini adalah Karyawan Bank Tabungan Negara Syariah KC Malang yang berjumlah 50 karyawan. Besarnya sampel ditetapkan pada penelitian ini menggunakan rumus Slovin. Dengan menggunakan rumus Slovin didapat jumlah responden dalam penelitian ini yaitu sebanyak 44 karyawan. Dalam penelitian ini teknik pengambilan sampel dilakukan dengan metode secara acak sederhana (simple random sampling) pada karyawan Bank Tabungan Negara Syariah KC Malang.

\section{Hasil dan Analisis}

\subsection{Etos Kerja Islami}

Berdasarkan tabel hasil Uji t, diketahui t hitung etos kerja Islami (X1) memiliki nilai 2,074 lebih besar dibandingkan t tabel yang memiliki nilai 2,01954 dengan sig 0,044 lebih kecil dari 0,05. Dengan demikian $t$ hitung $>t$ tabel maka hipotesis alternatif atau Ha diterima yang artinya variabel etos kerja Islami berpengaruh positif terhadap kinerja karyawan Bank Tabungan Negara Syariah KC Malang. Karyawan Bank Tabungan Negara Syariah KC Malang telah menerapkan etos kerja Islami dengan baik. Hal ini dinilai melalui 3 indikator yaitu: kerja merupakan penjabaran akidah, kerja dilandasi ilmu, serta amal shaleh yaitu bekerja mengikuti petunjuk-petunjuk Nya. 
Dengan adanya etos kerja Islami yang tinggi pada setiap individu karyawan maka akan mendorong karyawan melakukan kerja yang terbaik. Hal ini selaras dengan penelitian ini yang menunjukkan adanya pengaruh yang signifikan antara etos kerja Islami terhadap kinerja karyawan Bank Tabungan Negara Syariah KC Malang. Mayoritas individu karyawan sudah memiliki etos kerja yang baik sehingga karyawan mampu memberikan kinerja yang maksimal.

Tabel 4.1: Hasil Uji t

Coefficients ${ }^{\mathrm{a}}$

\begin{tabular}{|c|c|c|c|c|c|}
\hline \multirow{2}{*}{ Model } & \multicolumn{2}{|c|}{ Unstandardized Coefficients } & \multirow{2}{*}{$\begin{array}{c}\begin{array}{c}\text { Standardized } \\
\text { Coefficients }\end{array} \\
\text { Beta }\end{array}$} & \multirow{2}{*}{$\mathrm{t}$} & \multirow{2}{*}{ Sig. } \\
\hline & $\mathrm{B}$ & Std. Error & & & \\
\hline (Constant) & 3,610 & 6,207 & &, 582 &, 564 \\
\hline Etos_Kerja_Islami & ,339 &, 163 &, 280 & 2,074 &, 044 \\
\hline $\begin{array}{l}\text { Komitmen_Organi } \\
\text { sasi }\end{array}$ & ,422 &, 138 & ,413 & 3,059 &, 004 \\
\hline
\end{tabular}

Sumber: data diolah 2018

\subsection{Komitmen Organisasi}

Berdasarkan tabel di atas diketahui t hitung komitmen organisasi (X2) memiliki nilai 3,059 lebih besar dibandingkan t tabel yang memiliki nilai 2,01954 dengan sig 0,004 lebih kecil dari 0,05. Dengan demikian $t$ hitung $>t$ tabel maka hipotesis alternatif atau Ha diterima yang artinya adalah variabel komitmen organisasi memberikan pengaruh yang positif terhadap kinerja karyawan Bank Tabungan Negara Syariah KC Malang. Hasil analisis yang yang diperoleh menunjukkan bahwa komitmen organisasi mampu memberikan pengaruh signifikan terhadap kinerja karyawan. Karyawan Bank Tabungan Negara Syariah KC Malang telah memiliki komitmen organisasi yang tinggi. Hal ini dinilai melalui 3 indikator yaitu: komitmen afektif, komitmen kelanjutan, dan komitmen normatif. Dengan adanya komitmen organisasi yang tinggi pada setiap individu karyawan maka akan mendorong karyawan melakukan kerja yang terbaik untuk tercapainya tujuan organisasi perusahaan.

\subsection{Uji Simultan}

Pengujian secara simultan (uji f) bertujuan untuk mengetahui apakah semua variabel independen mempunyai pengaruh secara bersama-sama terhadap variabel 
dependen. Dalam pengujianini dapat dilakukan dengan cara membandingkan nilai $\mathrm{f}$ hitung dengan $\mathrm{f}$ tabel. Uji f dapat diketahui pada tabel berikut,

Tabel 4.2.: Hasil Uji f

ANOVA $^{\mathrm{a}}$

\begin{tabular}{|c|c|c|c|c|c|c|}
\hline \multicolumn{2}{|c|}{ Model } & $\begin{array}{l}\text { Sum of } \\
\text { Squares }\end{array}$ & Df & $\begin{array}{l}\text { Mean } \\
\text { Square }\end{array}$ & $\mathrm{F}$ & Sig. \\
\hline \multirow{3}{*}{1} & Regression & 89,310 & 2 & 44,655 & 9,463 &, $000^{\mathrm{b}}$ \\
\hline & Residual & 193,485 & 41 & 4,719 & & \\
\hline & Total & 282,795 & 43 & & & \\
\hline
\end{tabular}

Sumber: Data diolah, 2018

Berdasarkan tabel diatas, f hitung memiliki nilai 9,463 lebih besar dibandingkan $\mathrm{f}$ tabel yang memiliki nilai 3.23 dengan probabilitas 0,00 lebih kecil dari 0,05 . Dengan demikian $\mathrm{f}_{\text {hitung }}>\mathrm{f}_{\text {tabel }}$ maka hipotesis alternatif diterima yang artinya adalah variabel etos kerja Islami dan komitmen organisasi secara bersamasama berpengaruh positif terhadap kinerja karyawan Bank Tabungan Negara Syariah KC Malang. Hasil pengujian ini menjawab hipotesis $\mathrm{H}_{3}$ bahwa etos kerja Islami dan komitmen organisasi secara bersama-sama berpengaruh signifikan terhadap kinerja karyawan.

\section{Kesimpulan}

Berdasarkan hasil penelitian mengenai pengaruh etos kerja Islami dan komitmen organisasi terhadap kinerja pegawai karyawan Bank Tabungan Negara Syariah KC Malang, maka dapat diambil kesimpulan sebagai berikut: pertama, berdasarkan hasil uji analisis regresi linier berganda secara parsial (uji t) diketahui bahwa etos kerja Islami berpengaruh signifikan terhadap kinerja karyawan. Begitu juga dengan komitmen organisasi yang memberikan pengaruh yang signifikan terhadap kinerja karyawan. Kedua, berdasarkan hasil uji analisis regresi linier berganda secara simultan (uji f) diketahui bahwa kedua variabel independen yaitu etos kerja Islami dan komitmen organisasi berpengaruh signifikan terhadap kinerja karyawan. 


\section{Daftar Pustaka}

Asifudin, Ahmad Janan. 2004. Etos Kerja Islami. Surakarta: Muhammadiyah University.

Buchori Moctar. 1994. Penelitian Pendidikan dan Pendidikan Islam di Indonesia. Jakarta: Ikip Muhammadiyah press.

Departemen Agama Republik Indonesia. 1971. Al-Qur'an dan Terjemahannya. Jakarta: Yayasan Penyelenggara Penerjemah Al-Qur'an.

Febriana, Mayya Puji. 2009. Pengaruh Etos Kerja Islam Terhadap Kinerja Karyawan Pada BPRS Artha Abadi Kabupaten Pati. Skripsi Fakultas Syariah. Semarang: IAIN

Fitrianto Fajar Rian. 2011. Pengaruh Etos Kerja Islam Terhadap Kinerja Karyawan PT BPRS Buana Mitra Perwira Purbalingga. Skripsi Fakultas Syariah. Semarang: IAIN

Febrianto, Nino Megiawan. 2016. Pengaru Etos Kerja Islam danKomitmen Organisasi Terhadap Kinerja Karyawan. Skripsi Fakultas Ekonomi dan Bisnis. Jakarta: Universitas Negeri Syarif Hidayatullah.

Ghozali, Imam. 2016. Aplikasi Analisis Multivariete Dengan Program IBM SPSS 23 .Semarang: Universitas Diponegoro.

Handoko. 2000. Manajemen Personalia dan Sumber Daya manusia. Yogyakarta: BPFE UGM

Ilyas, Yasli. 2002. Kinerja: Teori, Penelitian, dan Penilaian. Depok: Pustaka Kajian Ekonomi Kesehatan FKMUI

Luthans, Fred. (2006). Perilaku Organisasi. Yogyakarta: Andi.

Mangkunegara, Anwar Prabu. 2005. Evaluasi Kinerja. Bandung: Refika Aditama.

Mangkunegara, Anwar Prabu. 2005. Perencanaa dan Pengembangan Sumber Daya Manusia . Bandung: Refika Aditama.

Robbins 2004. Perilaku Organisasi. Jakarta: Salemba Empat.

Sugiyono. 2016. Metode Penelitian Kuantitatif, kualitatif, $R \& D$. Bandung: Alfabeta.

Tasmara, Toto. 2002. Membudayakan Etos Kerja Islami. Jakarta: Gema Insani. 